\title{
EU/Th AND ${ }^{14} \mathrm{C}$ ISOTOPE DATING OF LAKE SEDIMENTS FROM SACRED LAKE AND LAKE NKUNGA, KENYA
}

\author{
D.O. Olago ${ }^{1}$, F.A. Street-Perrott ${ }^{2}$, R.A. Perrott ${ }^{2}$, M. Ivanovich ${ }^{3}$ and D.D. Harkness ${ }^{4}$ \\ 1. Dept. of Geology, University of Nairobi, P.O. Box 30197, Nairobi, KENYA
}

2. Dept. of Geography, University of Wales Swansea, Swansea SA2 8PP, WALES

3. AEA Technology, Analytical Sciences Centre, 551 Harwell, Didcot, Oxfordshire OX11 ORA, UK

4. NERC Radiocarbon Laboratory, NEL Technology Park, East Kilbride, Glasgow G75 0QU, UK

\begin{abstract}
In the tropical regions, lake and swamp sediment core chronologies have traditionally been established solely by radiocarbon dating. In several instances, however, the radiocarbon sampling resolution has been coarse, entailing extrapolations over time periods where there may have been considerable change in sedimentation rates related, for example, to significant, albeit abrupt, palaeoclimatic and palaeoenvironmental change. Moreover, some cores may age-wise exceed the radiocarbon dating limit of ca.40,000 yr, thus entailing tenuous extrapolations of radiocarbon dates obtained in the younger sections of the core in order to obtain a whole core chronology. In this paper, the chronology of lake sediment cores retrieved from Sacred Lake and Lake Nkunga on the north-eastern flank of Mount Kenya is established using a combination of highresolution radiocarbon dating and experimental U/Th dating to circumvent the drawbacks mentioned above. The derived chronosequences, which show that these sediment records span almost the whole of the late Quaternary period, demonstrate the efficacy and synergism of these dating techniques.
\end{abstract}

\section{INTRODUCTION}

The continental records of palaeoclimatic and palaeoenvironmental change in the tropics during the late Quaternary period do not, generally, date beyond 40,000 $\mathrm{yr} \mathrm{BP}$, and in most cases cover only the period $30,000 \mathrm{yr}$ BP to the present day. In the few cases where they do, however, dating control is poor, based on linear extrapolations of radiocarbon dating in the upper parts of the sequences. Causes of low to middle latitude climate phenomena are still poorly understood, and this is partly related to the paucity of data and to the poor temporal resolution of significant climatic and environmental events/ changes in the geological past. In this paper, the efficacy of coupled radiocarbon and U/Th dating of organic sediments and tephra horizons to establish a firm chronology for lake sediment sequences spanning the late Quaternary period, is demonstrated.

On the basis of the radiocarbon dates obtained by Coetzee (1967) on a 12m core from Sacred Lake, it was suspected that the relatively longer sediment cores retrieved from Sacred Lake and Lake Nkunga in 1989 (see below) extended beyond the radiocarbon timescale. Experimental U/Th dating (on both the organic lake mud and volcanic ashes in the Sacred Lake cores, and the organic lake mud in Lake
Nkunga) was therefore carried out, in addition to highresolution radiocarbon dating (including both conventional and accelerator mass spectrometry (AMS) dating). AMS dating was used solely to resolve the period of occurrence of the Younger Dryas event between 10,000 and 11,000 yr $\mathrm{BP}$, consequently, its reliability over conventional radiocarbon dating after $c a .40,000 \mathrm{yr} \mathrm{BP}$ was not tested.

Radiocarbon dating of tephras provides only indirect ages because the organic material used for age determination comes from below the tephra layer, or from the overlying strata (Einarsson, 1986), and is in any case useful only in sediments younger than $c a .40,000$ years. U/Th dating techniques enable direct dating of the tephra layers and thus (presumably) yields more reliable dates, and has the added advantage that sediments up to $c a .300,000 \mathrm{yr}$ old can be dated (Ivanovich, 1982a).

\section{LOCATIONOF SITES}

Mount Kenya is an extinct, heavily denuded volcano that lies on the equator at about $37^{\circ} \mathrm{E}$. It has the shape of a convex dome, and is approximately $100 \mathrm{~km}$ broad at its base. It lies within the East African climatic zone, and exhibits vegetation zonation of a similar type to the other highland 
regions of East Africa (Hedberg, 1951; Coe, 1967; Baker, 1967; Coetzee, 1967; White, 1983). Sacred Lake, a closed crater lake occupying a basaltic explosion crater $c a .1 \mathrm{~km}$ across, is located at $0^{\circ} 03^{\prime} \mathrm{N}, 37^{\circ} 32^{\prime} \mathrm{E}$, at an altitude of $2,350 \mathrm{~m}$ a.s.l. in the humid montane rain forest of Mt. Kenya, where the mean annual rainfall is ca.1,780mm (Fig. 1). Lake Nkunga, a closed crater lake as well, is located at $0^{\circ} 07^{\prime} \mathrm{N}$, $37^{\circ} 36^{\prime} \mathrm{E}$, at an altitude of $1820 \mathrm{~m}$ a.s.l. in the dry montane forest of Mt. Kenya, where mean annual rainfall is ca.1,020mm (Fig. 1).
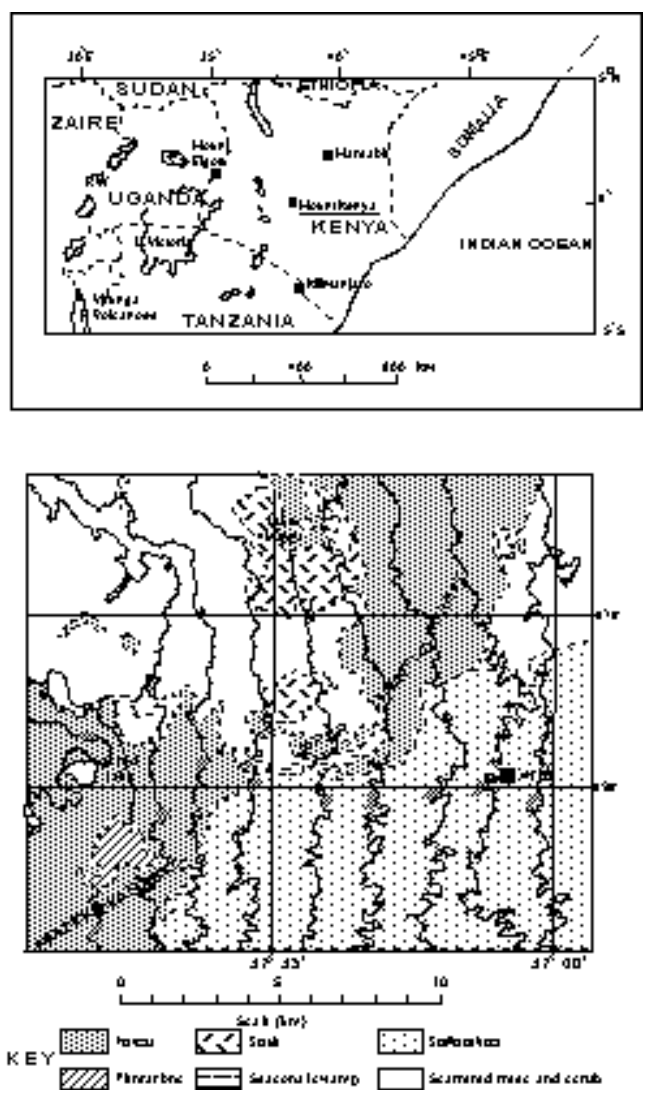

Fig. 1 Location of Sacred Lake and Lake Nkunga on the northeastern flank of Mount Kenya, Kenya.

\section{MATERIALS AND METHODS}

The lake sediments were retrieved using a raft-mounted Livingstone corer. The Sacred Lake cores were retrieved from an area of flat bed at a water depth of $2.5 \mathrm{~m}$. Two parallel cores (SL1, 1634cm; SL2, 1340cm) were obtained. The Lake Nkunga core $(\mathrm{NK} 1,2120 \mathrm{~cm})$ was retrieved from a water depth of $1.9 \mathrm{~m}$. The very sloppy top metre of sediment in each lake was sampled with a plastic core barrel. The cores were measured and the observable lithology described in the field. They were then wrapped in cling film, aluminium foil and sheet plastic, placed and sealed in hard plastic tubes and shipped to UK where they were put in cold storage $\left(4^{\circ} \mathrm{C}\right)$ at Oxford University.

The lengths of the discrete sections of the cores were remeasured in the laboratory to determine, and correct for, post-retrieval shrinkage, scanned for volume susceptibility, then sectioned longitudinally into two halves using a clean knife in a dust-free environment. The cores were then described in detail, and the Munsell Colour Chart was used to classify the colour changes in the sediment. After the description was completed, samples for radiocarbon and U/Th dating were taken particularly from positions where they bracketed lithological changes and directly from the ash layers for U/Th dating. In cases where a certain lithological unit was continuous for a fair length of the core, several samples from within the unit itself were taken for dating. The outer part of the core sections (in contact with the inner lining of the corer during extrusion) was cleaned to remove contaminants smeared down along the outer portion of the core during extrusion.

\section{Sediment Core Description}

\section{Sacred Lake Core SL1}

The two parallel Sacred Lake cores are very similar in terms of their lithological attributes, so the description of the cores presented is an amalgamated one, with, however, particular reference to core SL1. The principal sedimentary units are: waterlily peat, organic lake mud, sandy silt with organic lenses, root mats, volcanic ashes and diamicts. Of these sedimentary units, the organic lake mud is by far the most dominant (Fig. 2). The sediments are carbonate-free, and are diatomaceous except between 806 and $221 \mathrm{~cm}$ (core SL1), where diatoms are rare or absent. Zone III (1634 to $1248 \mathrm{~cm}$, core SL1; 1340 to $1245 \mathrm{~cm}$, core SL2) is characterised by diamicts and/or reworked volcaniclastic sediments at the bottom and top of the section in core SL1 - these sandwich an organic lake mud bed which contains a root mat and two tephra horizons (Fig. 2). The shorter core SL2 does not contain the basal diamict and ashes evident in core SL1. Zone II (1248 to $371 \mathrm{~cm}$, core SL1; 1245 to $355 \mathrm{~cm}$, core SL2) consists of an extensive organic lake mud bed with relatively thin root mats and three tephra horizons (Fig. 2). Zone I (371 to 0cm, core SL1; 355 to 0cm, core SL2) is dominated by a waterlily peat with varying proportions of plant macrofossils (Fig. 2). 


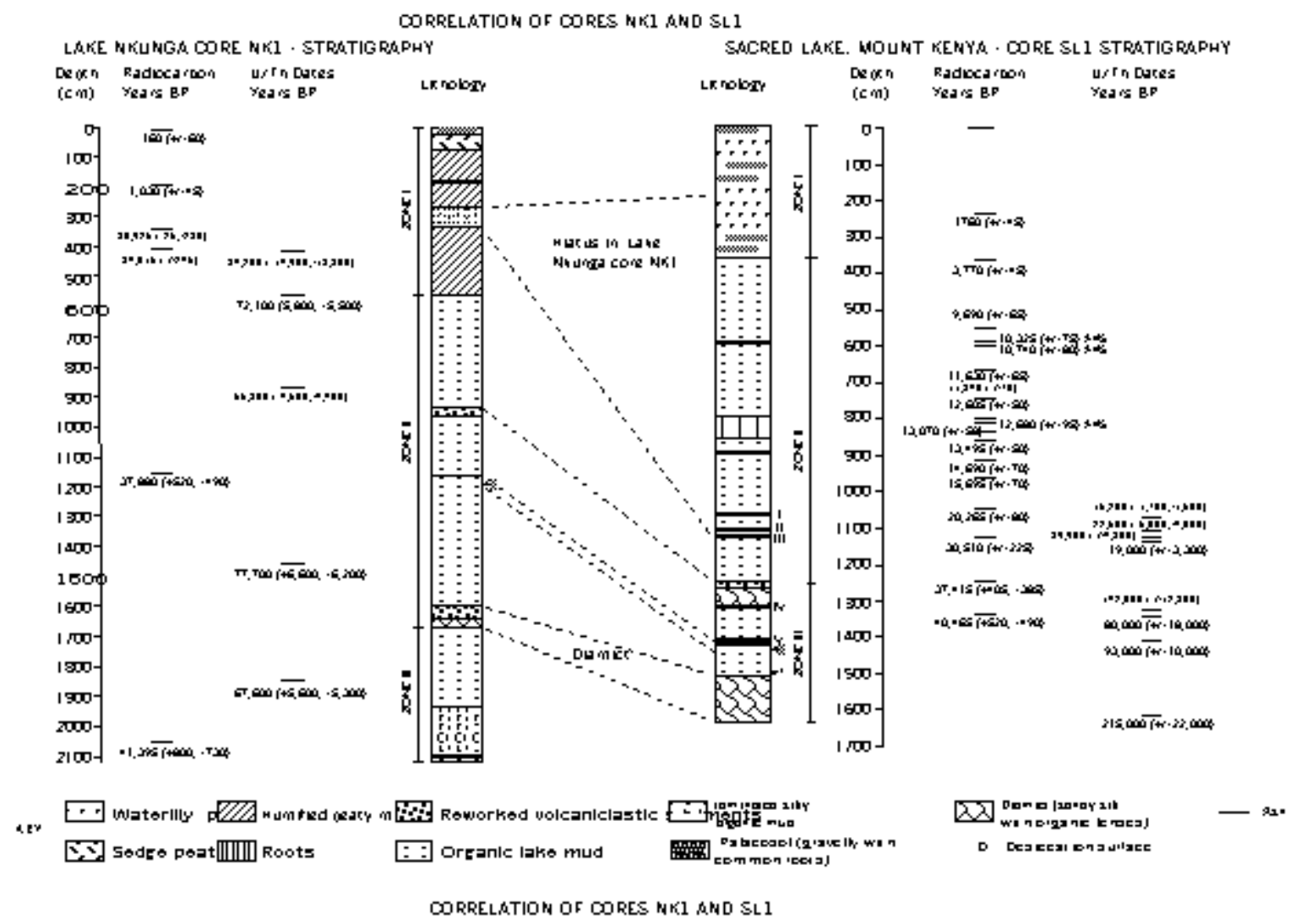

Fig. 2 Core stratigraphy and correlation of Sacred Lake core SL1 and Lake Nkunga core NK1.

\section{Lake Nkunga Core NKI}

The principal stratigraphic units in lake Nkunga are: waterlily peat, sedge peat, humified peaty mud, graded and laminated sandy to organic silt, organic lake mud, organic silt, and a gravelly palaeosol (Fig. 2). Plant macrofossils also occur within the diatom-rich sediment sequence, mainly in the upper sections. In Zone III (2020 to $1653 \mathrm{~cm}$ ), silty organic sediments, which are strongly laminated in the basal section of the core, are dominant. Zone II ( 1653 to $562 \mathrm{~cm})$ is dominated by a colour-banded organic lake mud bed (Fig. 2). Other units include: a diamict similar to those in the Sacred Lake core at the base of the zone $(1653$ to $1630 \mathrm{~cm})$, and an organic silt belt between 972 and $938 \mathrm{~cm}$. Zone I $(562$ to $0 \mathrm{~cm})$ is characterised by humified peaty mud containing abundant macrofossils (Fig. 2).

\section{Sample Preparation and Analysis}

\section{Radiocarbon Dating}

Samples selected were cut from the core with a clean knife with exceptional care being taken to ensure that there was no contamination by material from other sections of the core. For conventional radiocarbon dating, core sections $6 \mathrm{~cm}$ in length were taken, and, for accelerator mass spectrometry (AMS) dating, $1 \mathrm{~cm}$ length slices were taken. Prior to ${ }^{14} \mathrm{C}$ assay, the samples were digested in $0.5 \mathrm{M} \mathrm{HCL}$ (at $80^{\circ} \mathrm{C}$ for 24 hours), washed acid free with distilled water, filtered and oven-dried to constant weight, then oxidised quantitatively to $\mathrm{CO}_{2}$. For AMS measurements of the Sacred Lake sediments, aliquots of $\mathrm{CO}_{2}$ gas prepared at NERC Radiocarbon Laboratory were forwarded to the University of Arizona NSF-AMS Facility for ${ }^{14} \mathrm{C}$ assay. Lake Nkunga samples were ${ }^{14} \mathrm{C}$ assayed at the Radiocarbon Accelerator Unit, Oxford.

\section{U/Th Dating}

\section{The Organic Lake Mud/Peat}

An impure carbonate leachate fraction was obtained by $0.1 \mathrm{M} \mathrm{HNO}_{3}$ digestion of each of the samples (1 $\mathrm{cm}$ slices) and separated into three aliquots. The ${ }^{238} \mathrm{U},{ }^{234} \mathrm{U},{ }^{232} \mathrm{Th}$ and ${ }^{230} \mathrm{Th}$ concentration activity within the aliquots were then measured by alpha spectrometry (units: disintegrations 
per minute per gram $(\mathrm{dpm} / \mathrm{g}))$. The ${ }^{238} \mathrm{U},{ }^{234} \mathrm{U},{ }^{232} \mathrm{Th}$ and ${ }^{230} \mathrm{Th}$ concentration activity within the residues was also measured as an aid to correct the leachate data for detrital contamination (Ku and Liang, 1984). The correction (L-L) method (which utilises the plotting of normalised ${ }^{238} \mathrm{U},{ }^{234} \mathrm{U}$ and ${ }^{230} \mathrm{Th}$ activities to the ${ }^{232} \mathrm{Th}$ activity obtained for the three aliquots to obtain pure carbonate fraction ${ }^{230} \mathrm{Th} /{ }^{234} \mathrm{U}$ and ${ }^{234} \mathrm{U} /{ }^{238} \mathrm{U}$ activity ratios) (Ku and Liang, 1984) was then used to obtain the pure carbonate fraction age.

\section{The Tephras}

The samples were cleaned in acetone to avoid leaching of $\mathrm{U} / \mathrm{Th}$ isotopes, and then air-dried. Between 5 to $10 \mathrm{~g}$ of the sand- to coarse silt-sized fraction (differentiated by mechanical sieving) was taken from each of the ash units. After drying, the samples were run several times through an isodynamic magnetic separator to separate out the magnetic mineral components. The magnetic component was then stored in air-tight plastic bottles. The nonmagnetic component was then further differentiated into glass-rich and non-glass components by centrifugal differentiation in an acetone-bromoform mixture of specific density 2.42 . The non-glass component $(>2.42 \mathrm{sg})$ was further divided into two fractions (a 2.42 to $2.86 \mathrm{~s}$.g. fraction and a $>2.86$ s.g. fraction using an acetone-bromoform mixture of s.g. 2.86). Samples were air-dried then stored in labelled, air-tight, plastic bottles. The ${ }^{238} \mathrm{U},{ }^{234} \mathrm{U},{ }^{232} \mathrm{Th}$ and ${ }^{230} \mathrm{Th}$ concentration activity of the mineral separates were then measured by alpha spectrometry. The mineral separates ${ }^{230} \mathrm{Th} /{ }^{232} \mathrm{Th}$ and ${ }^{238} \mathrm{U} /{ }^{232} \mathrm{Th}$ were plotted against each other and from the isochron plot the age was determined.

\section{THEORY OF DATING METHODS}

Radiometric dating is based on the depletion or development of an isotope resulting from radioactive decay. Cosmogenic isotopes (e.g. ${ }^{14} \mathrm{C},{ }^{39} \mathrm{~K}$ ), artificially produced isotopes (e.g. ${ }^{137} \mathrm{Cs},{ }^{239,240} \mathrm{Pu}$ ), and members of the natural radioactive decay series (e.g. ${ }^{210} \mathrm{~Pb},{ }^{228,230} \mathrm{Th},{ }^{226} \mathrm{Ra}$ ) may be trapped in some medium to constitute a closed system, where there is, theoretically, no gain or loss in the isotope except for radioactive decay. By measuring the remaining activity, one can determine the time that has elapsed since the initial isolation, provided the initial activity is known. In a series decay, the daughter isotope will grow to reach secular equilibrium with the mother isotope (if separated from the mother isotope). The degree of this increase may be measured and used as a dating method e.g. for ${ }^{230} \mathrm{Th}$ and ${ }^{231} \mathrm{~Pa}$. The dating techniques applied to the sediments in this study are ${ }^{14} \mathrm{C}$ and experimental U/Th dating.

\section{${ }^{14} \mathrm{C}$ Isotope Dating Method}

${ }^{14} \mathrm{C}$ dating is one of the most widely applied dating techniques, although its application is limited to fairly young geological samples ( $c a .40,000$ years) due to the relatively short half life of the ${ }^{14} \mathrm{C}$ isotope. ${ }^{14} \mathrm{C}$ is taken up by plants and animals from the atmosphere as $\mathrm{CO}_{2}$. When the plants and animals die, the radiocarbon content starts to decrease. The decreasing ${ }^{14} \mathrm{C}$ content is a measure of age. Fundamental to the principles of radiocarbon dating is the assumption that atmospheric ${ }^{14} \mathrm{C}$ levels have remained constant during the period useful for ${ }^{14} \mathrm{C}$ dating. It is now clear that this assumption is not valid, though it is not a critical problem, and its magnitude can be assessed (Bradley, 1985; Stuiver et al., 1990). Possible causes of radiocarbon fluctuations include: variations in the cosmic ray-flux throughout the solar system and its modulation by solar activity; variations in the rate of exchange of radiocarbon between various geochemical reservoirs and changes in the relative carbon dioxide content of the reservoirs; variations in the amount of carbon dioxide in the atmosphere, biosphere and hydrosphere as a result of e.g. volcanism; changes in the sedimentation rates of $\mathrm{CO}_{2}$ sinks and hence in the atmospheric concentration of $\mathrm{CO}_{2}$; and combustion of fossil fuels by human industrial and domestic activity (Damon et al., 1978; Siegenthaler et al., 1980; Stuiver et al., 1990).

\section{U/Th Dating Method}

Uranium and weathering products containing uranium are highly soluble, whereas other products of the uranium series e.g. thorium and protactinium are readily absorbed and precipitated, and thus fractionation of these decay products occurs (Ivanovich, 1982a). Accumulating sediments will contain quantities of thorium and protactinium but will be deficient in uranium (Ivanovich, 1982a; Rosholt, 1982). In theory therefore, the age of e.g. lake and ocean sediments can be computed by measuring the rate of decay of thorium or protactinium within the sediments (Ivanovich, 1982a; Rosholt, 1982).

The disequilibrium method (employed in this study) measures the accumulation of daughter products of uranium: two different procedures are used in the preparation and age determination of the peat/organic lake muds and the tephra layers, respectively. The theory relating to each of the two methods is outlined below.

\section{The Peat/Organic Lake Mud}

Since lake (and ocean) waters contain $U$ but negligible amounts of ${ }^{231} \mathrm{~Pa}$ and ${ }^{230} \mathrm{Th}$, the extent to which the latter 
Table 1 Conventional (code SRR) and AMS (code AA) radiocarbon dates, and experimental U/Th dates in Sacred Lake cores SL1 and SL2.

A - RADIOCARBON AND U/Th DATES, SACRED LAKE CORE SL1

\begin{tabular}{|r|r|r|}
\hline \multicolumn{2}{|c|}{ SACRED LAKECORE SL1 } \\
\hline $\begin{array}{r}\text { Sample } \\
\text { Number }\end{array}$ & $\begin{array}{c}\text { Depth } \\
(\mathrm{cm})\end{array}$ & \multicolumn{1}{c|}{$\begin{array}{c}\text { C-14 Dates } \\
\text { Yr B.P. }\end{array}$} \\
\hline SRR-4750 & 242 & $1760( \pm 45)$ \\
\hline SRR-4751 & 365 & $3770( \pm 45)$ \\
\hline SRR-4752 & 563 & $9690( \pm 65)$ \\
\hline AA-9947 & 590 & $10325( \pm 75)$ \\
\hline AA-9948 & 602 & $10740( \pm 80)$ \\
\hline SRR-4753 & 663 & $11630( \pm 65)$ \\
\hline SRR-4754 & 741 & $11840( \pm 80)$ \\
\hline SRR-4755 & 794 & $12605( \pm 50)$ \\
\hline AA-9949 & 811 & $12680( \pm 95)$ \\
\hline SRR-4756 & 835 & $13070( \pm 50)$ \\
\hline SRR-4757 & 860 & $13495( \pm 50)$ \\
\hline SRR-4758 & 913 & $14690( \pm 70)$ \\
\hline SRR-4759 & 957 & $15695( \pm 70)$ \\
\hline SRR-4760 & 1041 & $20265( \pm 80)$ \\
\hline SRR-4761 & 1128 & $30510( \pm 225)$ \\
\hline SRR-4762 & 1244 & $37415(+405,-385)$ \\
\hline SRR-4763 & 1339 & $40465(+520,-490)$ \\
\hline
\end{tabular}

\begin{tabular}{|r|r|r|}
\hline \multicolumn{3}{|c|}{ SACRED LAKE CORE SL1 } \\
\hline $\begin{array}{r}\text { Sample } \\
\text { Number }\end{array}$ & $\begin{array}{c}\text { Depth } \\
(\mathrm{cm})\end{array}$ & $\begin{array}{c}\text { U/Th Dates } \\
\text { Yr B.P. }\end{array}$ \\
\hline Ash I & 1067 & $15200(+1700,-1600)$ \\
\hline Ash II & 1106 & $22500(+5000,-4000)$ \\
\hline Ash III & 1125 & $39900( \pm 4800)$ \\
\hline Peat & 1132 & $19000( \pm 3300)$ \\
\hline Ash V & 1321 & $142100( \pm 12800)$ \\
\hline Peat & 1334 & $80000( \pm 18000)$ \\
\hline Peat & 1414 & $93000( \pm 10000)$ \\
\hline Peat & 1618 & $215000( \pm 22000)$ \\
\hline
\end{tabular}

\section{B - RADIOCARBON AND U/Th DATES, SACRED LAKE CORE SL2}

\begin{tabular}{|c|r|r|}
\hline \multicolumn{3}{|c|}{ SACRED LAKE CORE SL2 } \\
\hline $\begin{array}{l}\text { Sample } \\
\text { Number }\end{array}$ & $\begin{array}{c}\text { Depth } \\
(\mathrm{cm})\end{array}$ & $\begin{array}{c}\text { C-14 Dates } \\
\text { Yr B.P. }\end{array}$ \\
\hline SRR-4517 & 350 & $3210( \pm 50)$ \\
\hline SRR-4518 & 531 & $9185( \pm 80)$ \\
\hline SRR-4519 & 601 & $10750( \pm 50)$ \\
\hline SRR-4520 & 703 & $11820( \pm 50)$ \\
\hline SRR-4521 & 802 & $12475( \pm 55)$ \\
\hline SRR-4522 & 914 & $14755( \pm 60)$ \\
\hline SRR-4523 & 1010 & $18170( \pm 80)$ \\
\hline SRR-4524 & 1067 & $23965( \pm 80)$ \\
\hline SRR-4525 & 1104 & $28760( \pm 200)$ \\
\hline SRR-4526 & 1124 & $29820( \pm 210)$ \\
\hline SRR-4527 & 1235 & $38450(+565,-530)$ \\
\hline SRR-4528 & 1313 & $38075(+545,-510)$ \\
\hline
\end{tabular}

\begin{tabular}{|r|c|c|}
\hline \multicolumn{3}{|c|}{ SACRED LAKE CORE SL2 } \\
\hline $\begin{array}{c}\text { Sample } \\
\text { Number }\end{array}$ & $\begin{array}{c}\text { Depth } \\
(\mathrm{cm})\end{array}$ & $\begin{array}{c}\text { U/Th Dates } \\
\text { Yr B.P. }\end{array}$ \\
\hline Ash I & 1061 & $28800( \pm 4300)$ \\
\hline Ash II & 1100 & $33900( \pm 2500)$ \\
\hline
\end{tabular}


two nuclides have reappeared in the sedimentary record is a direct reflection of age (Ivanovich, 1982a). The dating criteria applicable in this case relate to a closed system, and are as follows: (a) there should be no gain or loss of the parent nuclide since the time of its deposition, for example, the samples must be impermeable to groundwater because the flow of water through the system may cause an alteration in the $\mathrm{U}$ or Th content of the sediments; (b) there should be no weathering of the sample; (c) there should be little or no ${ }^{232} \mathrm{Th}$ (usually indicative of detrital contamination); (d) there should be no diagenetic change (Ivanovich, 1982b). If a sample contains no ${ }^{230} \mathrm{Th}$ at the time of formation, then at any later time the ${ }^{230} \mathrm{Th} /{ }^{234} \mathrm{U}$ ratio is given by the relationship:

$$
\begin{aligned}
& { }^{230} \mathrm{Th} /{ }^{234} \mathrm{U}=\left[\left(1-\mathrm{e}^{-} \lambda^{230 \mathrm{t}}\right) /\left({ }^{234} \mathrm{U} /{ }^{238} \mathrm{U}\right)\right] \\
& +\left[1-\left(1 /\left({ }^{234} \mathrm{U} /{ }^{238} \mathrm{U}\right)\right] \times\left\{\left[\lambda_{230} /\left(\lambda_{230}-\lambda_{234}\right)\right] \times[(1-\right.\right.
\end{aligned}
$$

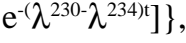

$$
\begin{aligned}
& \text { where } \lambda \text { is the decay constant of the }
\end{aligned}
$$

The age is then determined from an isochron (line of constant age but different ${ }^{234} \mathrm{U} /{ }^{238} \mathrm{U}$ activity ratio ) plot of the ${ }^{234} \mathrm{U} /{ }^{238} \mathrm{U}$ activity ratio against the ${ }^{230} \mathrm{Th} /{ }^{234} \mathrm{U}$ activity ratio, and the dating range in this technique is $350,000 \mathrm{yr}$ (Ivanovich, 1982a)

\section{The Tephra Units}

Chemical fractionation during magmatic processes (which ultimately may give rise to volcanic rocks and tephras) result in disequilibrium between parent uranium and daughter nuclides; the observed disequilibrium can be used to determine the age of crystallisation provided the magma reaches the surface in a time that is short relative to the half-lives of the nuclides involved (Harmon and Rosholt, 1982). U and Th are preferentially concentrated in late crystallising magmas and residual solutions because their large ionic radii preclude them from early crystallising silicates (Goldschmidt, 1954). Fractionation of ${ }^{234} \mathrm{U}$ from ${ }^{238} \mathrm{U}$ does not, however, occur during magmatic processes, and thus ${ }^{234} \mathrm{U}$ is not useful in volcanic rock chronological studies (Harmon and Rosholt, 1982). The ${ }^{230} \mathrm{Th} /{ }^{238} \mathrm{U}$ system is thus the most appropriate to apply to upper Quaternary volcanic rocks (and pyroclasts) because of its relatively long half-life of 75,200 yr. For a magmatic system initially in isotopic equilibrium and presuming a short transit time to the surface so that ${ }^{238} \mathrm{U}$ decay is negligible, a plot of ${ }^{230} \mathrm{Th} /{ }^{232} \mathrm{Th}$ against ${ }^{238} \mathrm{U} /{ }^{232} \mathrm{Th}$ for the individual mineral phases will define a horizontal line at the time of crystallisation $\mathrm{t}=0$ when the minerals have the same ${ }^{230} \mathrm{Th} /$ ${ }^{232} \mathrm{Th}$ ratios but different ${ }^{238} \mathrm{U} /{ }^{232} \mathrm{Th}$ ratios, because $\mathrm{U}$ and Th will not be partitioned to the same extent in the different mineral phases (Harmon and Rosholt, 1982). Thus, the ${ }^{230} \mathrm{Th} /{ }^{332} \mathrm{Th}$ and ${ }^{238} \mathrm{U} /{ }^{232} \mathrm{Th}$ mineral ratios will define an internal isochron whose slope will vary as a function of time according to the following relationship:

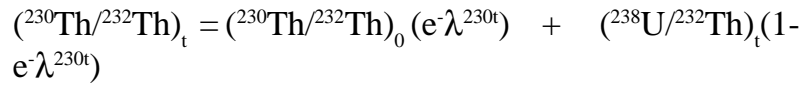

Fig. 2 Core stratigraphy and correlation of Sacred Lake core SL1 and Lake Nkunga core NK1.

and the ordinate intercept of the horizontal line defined by the mineral phases at $\mathrm{t}=0$ will be the initial $\left({ }^{230} \mathrm{Th} /{ }^{232} \mathrm{Th}\right)_{0}$ ratio of the whole system (Harmon and Rosholt, 1982). $\mathrm{The}{ }^{230} \mathrm{Th} /{ }^{232} \mathrm{Th}-{ }^{238} \mathrm{U} /{ }^{232} \mathrm{Th}$ activity ratios for the mineral phases will subsequently define a suite of lines (isochrons) whose slopes progressively change according to the time function $\left(1-e^{-230 t}\right)$, rotating about a point equal to the initial $\left({ }^{230} \mathrm{Th} /{ }^{232} \mathrm{Th}\right)_{0}$ ratio of the melt, and whose ordinate intercepts at any time $t$ are given by the relationship:

$$
\left({ }^{230} \mathrm{Th} /{ }^{32} \mathrm{Th}\right)_{\mathrm{t}}=\left({ }^{230} \mathrm{Th} /{ }^{232} \mathrm{Th}\right)_{0}\left(\mathrm{e}^{-\lambda} \lambda^{230 \mathrm{t}}\right)
$$

At secular equilibrium this line will reach a slope of unity and pass through the origin since, at that time, ${ }^{230} \mathrm{Th} /{ }^{232} \mathrm{Th}$ $={ }^{238} \mathrm{U} /{ }^{232} \mathrm{Th}$ (Harmon and Rosholt, 1982).

\section{RESULTS AND DISCUSSION}

\section{Sacred Lake Core Chronology}

The radiocarbon dates are internally consistent (as a function of depth) within each and also between the two cores (Table 1). However, it appears that its reliability as a dating technique for the Sacred Lake sediments rapidly deteriorates after ca.30,000 yr BP (subsequent events appear to be underestimated) (Table 1). Possible contamination by groundwater is not significant as this lake water budget is strongly dominated by direct precipitation inputs, and the young age at $242 \mathrm{~cm}(1760 \mathrm{yr}$ $\mathrm{BP})$ does not imply juvenile $\mathrm{CO}_{2}$ contamination.

On the other hand, some inconsistencies are observed in the U/Th dates dataset. The ash units and the organic lake mud samples dated form three separate and generally consistent subsets within the limits of experimental error: core SL1 ash, core SL2 ash, and core SL1 organic lake mud. However, when the three sets of dates are combined, inconsistencies are observed such as age inversions with increasing depth, e.g., between: SL1 ash I (1067cm depth, 15,200 yr BP) and SL2 Ash II (1061 cm depth, 28,800 yr BP); SL1 organic lake mud (1132cm depth, 19,000 yr BP) and SL1 Ash III (1125cm depth, 39,900 yr BP); and SL1 Ash IV 
Table 2 Conventional (code SRR) and AMS (code AA) radiocarbon dates, and experimental U/Th dates in Lake Nkunga core NK1.

\section{RADIOCARBON AND U/Th DATES, LAKE NKUNGA CORE NK1}

\begin{tabular}{|r|r|r|}
\hline \multicolumn{3}{|l|}{ LAKE NKUNGA CORE NK1 } \\
\hline $\begin{array}{r}\text { Sample } \\
\text { Number }\end{array}$ & $\begin{array}{r}\text { Depth } \\
(\mathrm{cm})\end{array}$ & \multicolumn{1}{c|}{$\begin{array}{c}\text { C-14 Dates } \\
\text { Yr B.P. }\end{array}$} \\
\hline OXA-3502 & 10 & $160( \pm 60)$ \\
\hline SRR-4764 & 190 & $1030( \pm 45)$ \\
\hline SRR-4579 & 340 & $30925( \pm 235)$ \\
\hline SRR-4765 & 411 & $34015( \pm 245)$ \\
\hline SRR-4580 & 1158 & $37880(+520,-490)$ \\
\hline SRR-4581 & 2061 & $41395(+800,-730)$ \\
\hline
\end{tabular}

\begin{tabular}{|c|r|r|}
\hline \multicolumn{3}{|c|}{ LAKE NKUNGA CORE NK1 } \\
\hline $\begin{array}{c}\text { Sample } \\
\text { Number }\end{array}$ & $\begin{array}{c}\text { Depth } \\
(\mathrm{cm})\end{array}$ & $\begin{array}{c}\text { U/Th Dates } \\
\text { Yr B.P. }\end{array}$ \\
\hline NK1 1172 & 408 & $84200(+14900,-13300)$ \\
\hline NK2 1174 & 558 & $72100(+5800,-5500)$ \\
\hline NK3 1176 & 870 & $56800(+4600,-4400)$ \\
\hline NK4 1178 & 1450 & $77700(+6600,-6200)$ \\
\hline NK5 1180 & 1844 & $67600(+5600,-5300)$ \\
\hline
\end{tabular}

(1321 cm depth, 142,000 yr BP), and peats at $1334 \mathrm{~cm}(80,000$ yr BP) and $1414 \mathrm{~cm}(93,000 \mathrm{yr}$ BP) (Table 1). The ash IV U/ Th date can however be rejected on the basis of an extremely poor linear best fit line obtained for the pseudo-isochron dating method. The U/Th date of $215,000 \mathrm{yr} \mathrm{BP}$ at $1618 \mathrm{~cm}$ was derived from a disturbed organic lake mud unit sandwiched within a relatively thick diamict unit and can be rejected on the basis of contamination by reworked volcaniclastic sediment which contain Th isotopes whose presence invalidates the basic assumption that no ${ }^{230} \mathrm{Th}$ was initially present (e.g. Rowe et al., 1989). Ash V (1321cm) was also similarly contaminated.

The U/Th dates with values less than 25,000 yr BP (e.g. at $15,200 \mathrm{yr}$ BP for Ash I $(1067 \mathrm{~cm})$ and 19,000 yr BP for the organic lake mud $(1132 \mathrm{~cm})$ ) appear to underestimate the true dates considerably, the assumption being that the radiocarbon ages for this time period are reliable. Conversely, the dates obtained from ashes III and V are both too old, given that the stratigraphic and palynological (Coetzee, 1967) evidence does not indicate that the sequence spanned the last interglacial.

Since each of the three U/Th dates subsets (described above) are a consistent and progressive function of depth, one would suspect that the inconsistencies in the universal set (as a function of depth) are due to inherent biases, such as may arise due to: the difficulties of sample preparation ( $c f$. Barrett et al., 1992), experimental error (Ivanovich, pers. comm.), in situ diagenetic processes (Ivanovich, 1982b) and contamination of the primary ashes by basement material during the eruption phase. Some preferential leaching of $U$ and $T h$ isotopes may occur as the deposit experiences interstitial fluids (Ivanovich, 1982a; Szabo and Rosholt, 1982), and this tends to reduce the disequilibrium and younger dates are obtained (Osmond and Cowart, 1982), and probably explains the age inversions observed. In oxidised waters, ${ }^{234} \mathrm{U}$ is relatively soluble (Ivanovich, 1982a; Osmond and Cowart, 1982) and thus the U/Th dates would also be dependent on the sediment accumulation rate which determines, in part, the amount of time the sediment deposited spends 
within the oxidation zone, and hence the degree to which ${ }^{234} \mathrm{U}$ is leached and solved.

A scatter plot of all the radiocarbon and U/Th dates indicates that the age-depth function is non-linear (Fig. 3). A histogram plot of the distribution of the dates (with midpoints at every 20,000 years) indicates that the distribution is highly positively skewed. To make these dates amenable to statistical analysis (i.e. to make the distribution approach a 'normal' curve, and enable its description by a linear equation of the form $y=m x+c)$, the dates were converted to logarithmic form. Regression analysis was then performed, taking age as a function of depth. This regression curve has a high regression coefficient (ca.0.95), but also has large residuals (Figs. 3 and 4). It appears to compensate well for sediment autocompaction, but fails to account for the variable sedimentation rates which are generally influenced by climatic and catchment-intrinsic variables (Fig. 3).

A second more complex, cubic regression curve was therefore fitted. The resulting regression curve fits the data quite well from $600 \mathrm{~cm}$ to the bottom of the core (Fig. 3 ). Above $600 \mathrm{~cm}$, the fit becomes increasingly poor with decreasing depth, as evidenced by the high residuals observed (Figs. 3 and 4). The radiocarbon dates within this range (0 to $600 \mathrm{~cm})$ are however considered to be experimentally and stratigraphically reliable. It is therefore

SACRED LAFE CHRONOLOGU

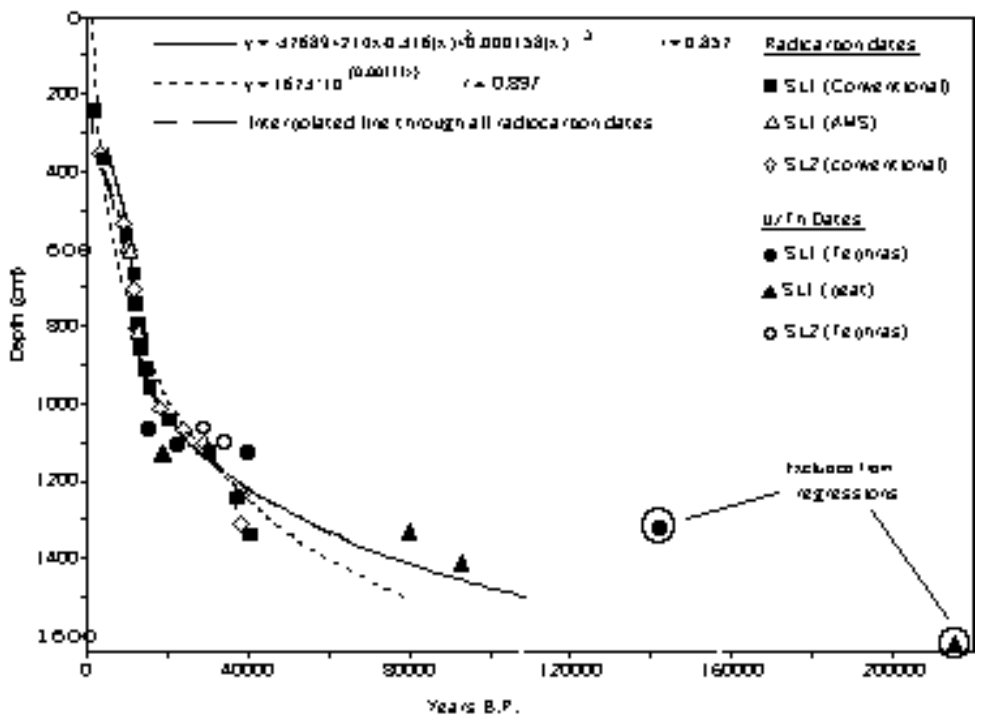

Fig. 3 Sacred Lake chronology.

apparent that a combination of an interpolated curve from 0 to $600 \mathrm{~cm}$ depth, coupled with the cubic regression curve from $600 \mathrm{~cm}$ to the base of the core is justified. This combination is further supported by the consistency and extremely low residuals between the two regression curves over the range in which radiocarbon dating is considered to be a reliable indicator of age (Fig. 3). The age at the base of the core is shown to be ca.160,000 yr BP (Fig. 3), and is considered to be too old, since there is no apparent stratigraphic record of the last interglacial period, and the unit at the base of core SL1 (at ca.1512 to $1634 \mathrm{~cm}$ depth) is a diamict with characteristics that suggest rapid deposition during a cold climate phase (Olago, 1995). The age in the lower portion of the core can therefore be calculated with some index of certainty up to $c a .1512 \mathrm{~cm}$ depth. Below $1512 \mathrm{~cm}$, an attempt to quantify the age of the sediments is considered untenable. A maximum basal age of $c a .115,000$ yr BP - the last interglacial-glacial transition - can however be set for the core. Although the core chronology has been derived from a combination of uncalibrated radiocarbon dates and $U / T h$ dates in calendar years, this is not a critical problem given the large error margins of the $\mathrm{U} / \mathrm{Th}$ dates. 


\section{THE RESIDUALS TO REGRES SION CUAYE}

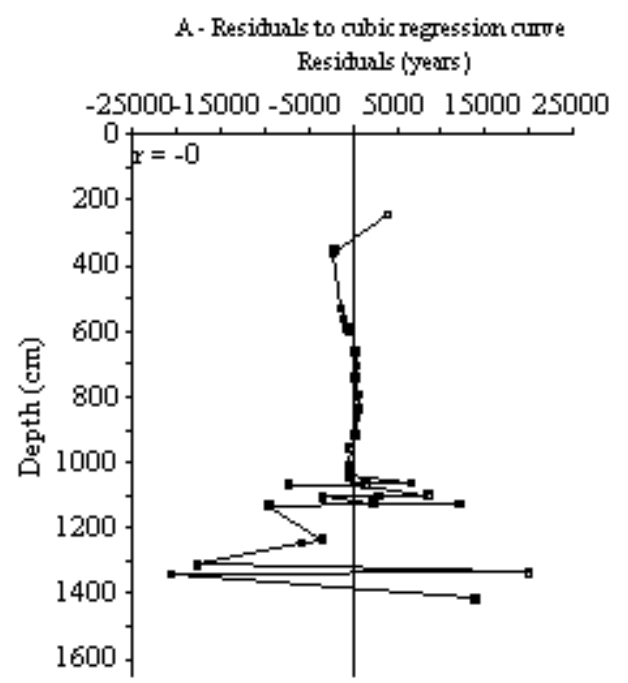

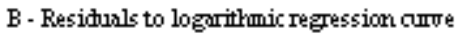
Fesidusle (yeirs!

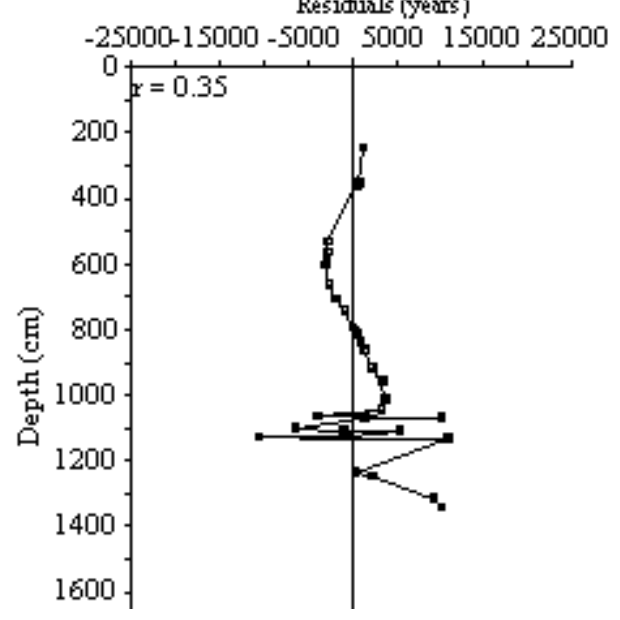

Fig 4 The residuals to the cubic and logarithmic regression curves fitted to the Sacred Lake dates.

\section{Lake Nkunga Core Chronology}

Six radiocarbon dates and five U/Th dates were obtained for Lake Nkunga core NK1 (Table 2). The dates show that the radiocarbon timescale limit is exceeded at $c a .400 \mathrm{~cm}$, while the core is $2120 \mathrm{~cm}$ long. The experimental U/Th dates, on the other hand, are not in stratigraphic sequence.
These two sets of dates are discussed separately below, following which the data is synthesised to derive a chronology for the lake sediment core.

The radiocarbon dates immediately below and above the palaeosol bed are 1,030 and 30,925 yr BP respectively, indicating that the late Pleistocene and much of the Holocene record is missing. Linear extrapolation of the $1,030 \mathrm{yr} \mathrm{BP}$ radiocarbon date (assuming $0 \mathrm{yr} \mathrm{BP}$ at the surface, and a constant sedimentation rate from the top of the gravelly clay overlying the palaeosol bed at $264 \mathrm{~cm}$ (where peat begins to accumulate) to $0 \mathrm{yr} \mathrm{BP}$ ) puts an upper age limit of $c a .1,430 \mathrm{yr}$ BP for the sedimentary hiatus. The beginning of the hiatus is most probably causally linked to the eruption of Ash III, recorded in Sacred Lake sediments. Ash III is a greyish brown, fine sand to granulesized tephra of local significance, and its macroscopic features tie in well with the lithological characteristics of the palaeosol bed (see below). In the field, a narrow, deep, breach of the crater wall was observed on the eastern side of the basin (the lake was accessed through this gap) - this breach presently limits the lake level maximum to not more than about $3 \mathrm{~m}$ above its present level. The hiatus can be perhaps be accredited to reactivation and consequent opening of a fissure in the crater due to tectonic movements resulting from a magma eruption process - this resulted in water loss from the basin up to $c a .1,430 \mathrm{yr} \mathrm{BP}$, when the fissure was finally plugged by sediment infilling, and lake sedimentation resumed. The sediment infilling at $c a .1,430$ yr BP may well be anthropogenic - this period coincides with a drought recorded in some East African sites (Bonnefille et al., 1986; Halfman and Johnson, 1988), and thus the lake may have served as an important water source.

The radiocarbon ages at 1158 and $2061 \mathrm{~cm}$ are probably infinite (Table 2). With the radiocarbon limits being exceeded at $c a .400 \mathrm{~cm}$, the implications are that the core spans, at the least, most of the late Quaternary, and it is possible that the diatom-rich, laminated organic sediments at the base of the core are of the last interglacial period. The U/Th dates do not resolve the sediment chronology as they are inconsistent with the stratigraphy (Table 2). These dates are also statistically indistinguishable from each other except for the sample at $870 \mathrm{~cm}$. All the samples can thus assumed to be coeval (deposition took place over a relatively short period of time (several thousand years at the most) compared with the half-life of ${ }^{230} \mathrm{Th}\left(\mathrm{t}_{1 / 2}=75,200\right.$ $\mathrm{yr})$ : the five-point pseudo-isochron plotting of the leachate data (L-L method, Ku and Liang, 1984) resulted in an age of $84,500 \pm 15,000 \mathrm{yr}$ for the whole sequence of dates, and the different ages previously obtained could represent different degrees of mixing of a sediment characterised by the same end members. The lake presently, however, has a 
significant groundwater recharge source (Olago, 1995), and this source probably played a significant role in the balancing of the lake's hydrological budget over the late Quaternary period; this groundwater recharge could thus have violated one of the assumptions of U/Th dating applicability, and may have been a determining cause of the stratigraphically aberrant dates.

The radiocarbon dates are generally not comparable with the U/Th dates due to the limitation of the former at only about $400 \mathrm{~cm}$ depth, and the internal inconsistencies of the latter. Given the arguments advanced for the cause and duration of the hiatus, the radiocarbon date at $340 \mathrm{~cm}(30,925$ yr BP) is probably close to the true age of the sample at that depth; the U/Th date of $84,200 \mathrm{yr} \mathrm{BP}$ at $408 \mathrm{~cm}$ is inconsistent with the radiocarbon date at $340 \mathrm{~cm}$, as well as with the other U/Th dates in the lower part of the profile. The U/Th dating technique is, however, relevant insofar as it attests to the antiquity of the sediments. What can be deduced of the chronological timespan of the Lake Nkunga sediments (from the results of the U/Th and radiocarbon dates coupled with the stratigraphic data), is that they probably span most or all of the late Quaternary period. Assuming, further, that the sedimentation rates in both Sacred Lake and Lake Nkunga over the late Quaternary period were more or less similar, and applying the Sacred Lake sediments logarithmic function (see above), then the Lake Nkunga basal sediments could be of the last interglacial period.

$\mathrm{F} \mathrm{ur} \mathrm{th}$ e $\mathrm{r}$ resolution of the Lake Nkunga core chronology can however be achieved by stratigraphic correlation with the Sacred Lake core which is better resolved chronologically. Coarse stratigraphic correlation with Sacred Lake core SL1 can be established using two firm stratigraphic control points: the hiatus (age established above) and the diamict at 1653 to $1630 \mathrm{~cm}$ (with corollaries in Sacred Lake). Since there are two diamict sections in Sacred Lake core SL1, there are two possible alternatives to correlating the diamicts within the two lake sediment cores. The Sacred Lake ashes III, II and I have no counterparts in the Lake Nkunga core as they were erupted during the erosion phase in Lake Nkunga. In case I (Fig. 2), the Lake Nkunga diamict has been correlated with the basal diamict in Sacred Lake core SL1. A tephra horizon at 1166 to $1161 \mathrm{~cm}$ in Lake Nkunga core NK1 (grey, fine to medium sized volcaniclastic sand), which appears not to resemble the Sacred Lake ashes, may be correlated to Ash V (Sacred Lake) on the basis of their similarity in mineral magnetic properties (i.e. volume susceptibility $\left(\chi_{\mathrm{v}}\right)$, mass specific susceptibility $(\chi)$, saturation isothermal remanent magnetism (SIRM - total magnetic mineral concentration), 'hard' isothermal remanent magnetism (HIRM - a measure of the haematite content), and SIRM/ $\chi$ ). Ash IV in Sacred Lake does not appear to have a corollary in Lake Nkunga and is thought to have been reworked in the organic silt bed (962 to $938 \mathrm{~cm})$, which is correlated with the temporally younger diamict and reworked volcaniclastic sediments in Sacred Lake core SL1 (Fig. 2). The desiccation surface at $1194 \mathrm{~cm}$ in core NK1 can also be correlated with the partial desiccation surface at 1544 to $1538 \mathrm{~cm}$ in core SL1. In case II, the basal diamict in core NK1 is correlated with the diamict and reworked volcaniclastic sediments between 1319 and $1245 \mathrm{~cm}$ in core SL1. In this case, however, it is impossible to establish any stratigraphic relationship with the desiccation surface and ash layer in core SL1, and it is consequently less likely to be correct. Nevertheless, these two correlations, and the dates, indicate that the zone III sediments in Lake Nkunga have a minimum age of about $60,000 \mathrm{yr}$ at the top (more likely 110,000 yr), and could extend back to $c a .130,000 \mathrm{yr} \mathrm{BP}$ at the base.

\section{CONCLUSIONS}

Coupled radiocarbon and U/Th dating of late Quaternary lacustrine sediments can help resolve chronologies of sequences that exceed that exceed the limits of radiocarbon dating techniques. The U/Th method as applied to organic sediments appears to be fairly sensitive to the hydrological, geological and sedimentological parameters particular to a sedimentary basin, thus, these parameters would need to be more thoroughly investigated in the field as an aid to elucidating the derived U/Th age estimates of lacustrine sequences. In the case of direct U/Th dating of the tephra horizons, it has been demonstrated that where pure mineral separates are hard to obtain due to the varying proportions of a diverse crystallite assemblage within a single grain such as in the Sacred Lake ashes, separating the components by virtue of their density differences as a means of enriching the mineral fractions is a viable and workable option, yielding good results by the pseudoisochron method.

\section{REFERENCES}

BAKER, B.H., 1967. Geology of the Mount Kenya Area. Geol. Surv. Kenya, Rep. 79, Nairobi, 78 pp.

BARRETT, P.J., ADAMS, C.J., McINTOSH, W.C., SWISHER III, C.C. and WILSON, G.S., 1992. Geochemical evidence supporting Antarctic deglaciation three million years ago. Nature, 359: 816-818.

BONNEFILLE, R., ROBERT, C., DELIBRIAS, G., ELENGA, C., HERBIN, J.P., L?ZINE, A.M., PERINET, G. and 
TIERCELIN, J.J., 1986. Palaeoenvironment of Lake Abiyata, Ethiopia, during the past 2000 years. In: L.E. FROSTICK, R.W. RENAUT, I. REID and J.-J. TIERCELIN (eds.), 1986, Sedimentation in the African Rifts. Geol. Soc. Spec. Publ. No. 25: 253-265.

BRADLEY, R.S., 1985. Quaternary Paleoclimatology: Methods of Paleoclimatic Reconstruction. Unwin Hyman, Boston, London. 472 pp.

COE, M.J., 1967. The Ecology of the Alpine Zone of Mount Kenya. Dr. W. Junk Publishers. 136 pp.

COETZEE, J.A., 1967. Pollen analytical studies in East and Southern Africa. Palaeoecol. Afr. 3: 146 pp.

DAMON, P.E., LERMAN, J.C. and LONG, A., 1978. Temporal fluctuations of atmospheric ${ }^{14} \mathrm{C}$ : causal factors and implications. Ann. Rev. Earth Planet. Sci., 6: 457-494.

EINARSSON, T., 1986. Tephrochronology. In: B.E. BERGLUND, (ed.), Handbook of Holocene Palaeoecology and Palaeohydrology. John Wiley and Sons, Chichester, 869 pp.

GOLDSCHMIDT, V.M., 1954. Geochemistry. Clarendon Press, Oxford.

HALFMAN, J.D and JOHNSON, T.C., 1988. Highresolution record of cyclic climatic change during the past 4ka from Lake Turkana, Kenya. Geology, 16: 496-500.

HARMON, R.S. and ROSHOLT, J.N., 1982. Igneous Rocks. In: M. IVANOVICH and R.S. HARMON (eds.), Uranium Series Disequilibrium: Applications to Environmental Problems, pp. 145-166. Clarendon Press, Oxford.

HEDBERG, O., 1951. Vegetation belts of the East African Mountains. Svensk. bot. Tidskr., 45: 140-202.

IVANOVICH, M., 1982a. Introduction. In: M. IVANOVICH and R.S. HARMON (eds.), Uranium Series Disequilibrium: Applications to Environmental Problems, pp. 1-33. Clarendon Press, Oxford.

IVANOVICH, M., 1982b. Uranium series disequilibria applications in geochronology. In: M. IVANOVICH and R.S. HARMON (eds.), Uranium Series Disequilibrium: Applications to Environmental Problems, pp. 56-78. Clarendon Press, Oxford.
KU, T.L. and LIANG, Z.C., 1984. The dating of impure carbonates with decay-series isotopes. Nucl. Instr. Meth., 223: 563-571.

OSMOND, J.K. and COWART, J.B., 1982. Groundwater. In: M. IVANOVICH and R.S. HARMON (eds.), Uranium Series Disequilibrium: Applications to Environmental Problems, pp. 202-245. Clarendon Press, Oxford.

ROSHOLT, J.N., 1982. Mobilisation and weathering. In: M. IVANOVICH and R.S. HARMON (eds.), Uranium Series Disequilibrium: Applications to Environmental Problems, pp. 167-180. Clarendon Press, Oxford.

ROWE, P.J., ATKINSON, T.C. and JENKINSON, R.D.S., 1989. Uranium-series dating of cave deposits at Creswell Crags Gorge, England. Cave Science, 16: 3-17.

SIEGENTHALER, U., HEIMANN, M. and OESCHGER, H., 1980. ${ }^{14} \mathrm{C}$ variations caused by changes in the global carbon cycle. Radiocarbon, 22: 177-191.

STUIVER, M., BRAZIUNAS, T.F., BECKER, B. and KROMER, B., 1990. Climatic, solar, oceanic, and geomagnetic influences on late glacial and Holocene atmospheric ${ }^{14} \mathrm{C} /{ }^{12} \mathrm{C}$ change. Quat. Res., 35: 1-24.

SZABO, B.J. and ROSHOLT, J.N., 1982. Surficial continental sediments. In: M. IVANOVICH and R.S. HARMON (eds.), Uranium Series Disequilibrium: Applications to Environmental Problems, pp. 246-267. Clarendon Press, Oxford.

WHITE, F., 1983. The Vegetation of Africa. UNESCO, 355 pp. 